\title{
Conservation issues and priorities in the Mikea Forest of south-west Madagascar
}

\author{
Nathalie Seddon, Joe Tobias, James W. Yount, Julien Rémi Ramanampamonjy, Stuart Butchart and \\ Hiarinirina Randrianizahana
}

\begin{abstract}
The dry forests constitute one of the most distinct, yet least protected, ecosystems in Madagascar, an island renowned for high levels of endemism. They have generally been considered one of the most intact of Madagascar's climax vegetation types and accordingly have received little conservation effort. In particular, the Mikea Forest, a unique area between the Mangoky and Fiherenana rivers, currently receives negligible formal protection. It contains remarkably diverse plant and reptile assemblages, including several taxa that are found nowhere else, plus the only populations of two threatened bird species: the subdesert mesite Monias benschi and long-tailed ground-roller Uratelornis chimaera. From satellite imagery we estimate that primary forest cover declined by 15.6 per cent from 1962 to 1999 , and that the rate of deforestation has increased from 0.35 per cent
\end{abstract}

per annum in 1962-94 to 0.93 per cent per annum over the past 5 years. The most important factors underlying this process are slash-and-burn maize cultivation in the northern Mikea Forest and charcoal production at its southern fringe. Given these alarming circumstances, we suggest that combinations of conservation measures are required to safeguard the biological diversity of the area. Specifically, we recommend the establishment of a large protected area to the north of Manombo, a coordinated network of community-based conservation areas throughout the Mikea Forest, development projects to improve agriculture, and a regional research and education centre.

Keywords Biodiversity, dry forest, Madagascar, Mikea Forest, threats.

\section{Introduction}

The dry forests of south and south-west Madagascar, previously referred to as 'West Malagasy Deciduous thicket' (White, 1983), 'South Malagasy spiny forests' (Stattersfield et al., 1998) and 'Deciduous Dry Southern Forest and Scrubland' (Du Puy \& Moat, 1996), stretch from the Mangoky river on the west coast to $c .40 \mathrm{~km}$ west of Fort Dauphin on the south-east coast. These forests were described as 'only too easy to clear and burn', such that little of their original cover remained (Curry-Lindahl, 1975). Further research resulted in the

\footnotetext{
Nathalie Seddon (corresponding author) and

Stuart Butchart Department of Zoology, Downing Street, Cambridge CB2 3EJ, UK. E-mail address:

ns10003@hermes.cam.ac.uk
}

Joe Tobias BirdLife International, Wellbrook Court, Girton Road, Cambridge $\mathrm{CB} 3$ ONA, UK

James W. Yount Land Resources Program, University of Wisconsin, WI, USA

Julien Rémi Ramanampamonjy Parc Botanique et Zoologique de Tsimbazaza, Antananarivo 101, Madagascar

Hiarinirina Randrianizahana Ministère des Eaux et Forets, Naninsana, Antananarivo 101, Madagascar

Revised manuscript accepted for publication 19 June 2000 more optimistic view that they are the most nearly intact of Madagascar's climax vegetation types' (Stattersfield et al., 1998). This optimism perhaps explains the fact that, although they have often been considered a high conservation priority (e.g. Domergue, 1983; Nicoll \& Langrand, 1989; WCMC, 1991; Raxworthy, 1995; ZICOMA, 1999), they have received very little conservation effort. Protected areas cover only c. 2 per cent of the total remaining forest in this region compared with c. 5.3 percent for lowland evergreen rainforest (Du Puy \& Moat, 1996).

Within these dry forests there are a variety of unique habitats supporting very different assemblages of plants and animals (Nicoll \& Langrand, 1989; WWF \& IUCN, 1994). One important area, the Mikea Forest, is found between the Fiherenana and Mangoky rivers (Fig. 1). Whilst the name 'Mikea Forest' is usually applied exclusively to the forest between the Manombo and Mangoky rivers, for simplicity we also allow the term to cover similar natural vegetation between the Manombo and Fiherenana rivers (Fig. 1), including areas previously referred to as 'PK32' (Nicoll \& Langrand, 1989) or 'Toliara' forest (Ganzhorn et al., 1997). We refer to the dry forests south of the Fiherenana river as the Southern Dry Forests. The Mikea Forest supports a rich flora and fauna with numerous locally endemic taxa that do not extend into the Southern Drv 
Forests. For example, it hosts the only populations of two threatened endemic bird species: the long-tailed ground-roller Uratelornis chimaera (Plate 1) and the subdosert mesite Monias benschi, as well as particularly rich communities of endemic reptiles (Raxworthy, 1995) and plants (Phillipson, 1996; Razanaka, 1996). The Mikea Forest has long been identified as extremely important for its biodiversity (e.g. Domergue, 1983; WCMC, 1991;
Ganzhorn et al., 1997), yet the area of natural habitat is contracting in size, becoming increasingly degraded and receives negligible formal protection (Nicoll \& Langrand, 1989; ZICOMA, 1999).

Collar \& Stuart (1988) judged that 'a study to determine the extent and type of habitat destruction in the area, with a view to identifying one or more key areas for protection, is urgently needed'. In this paper we

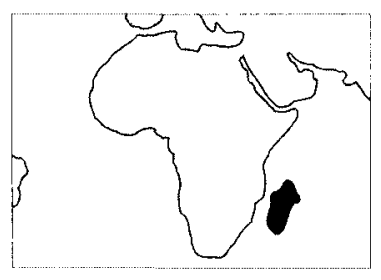

0
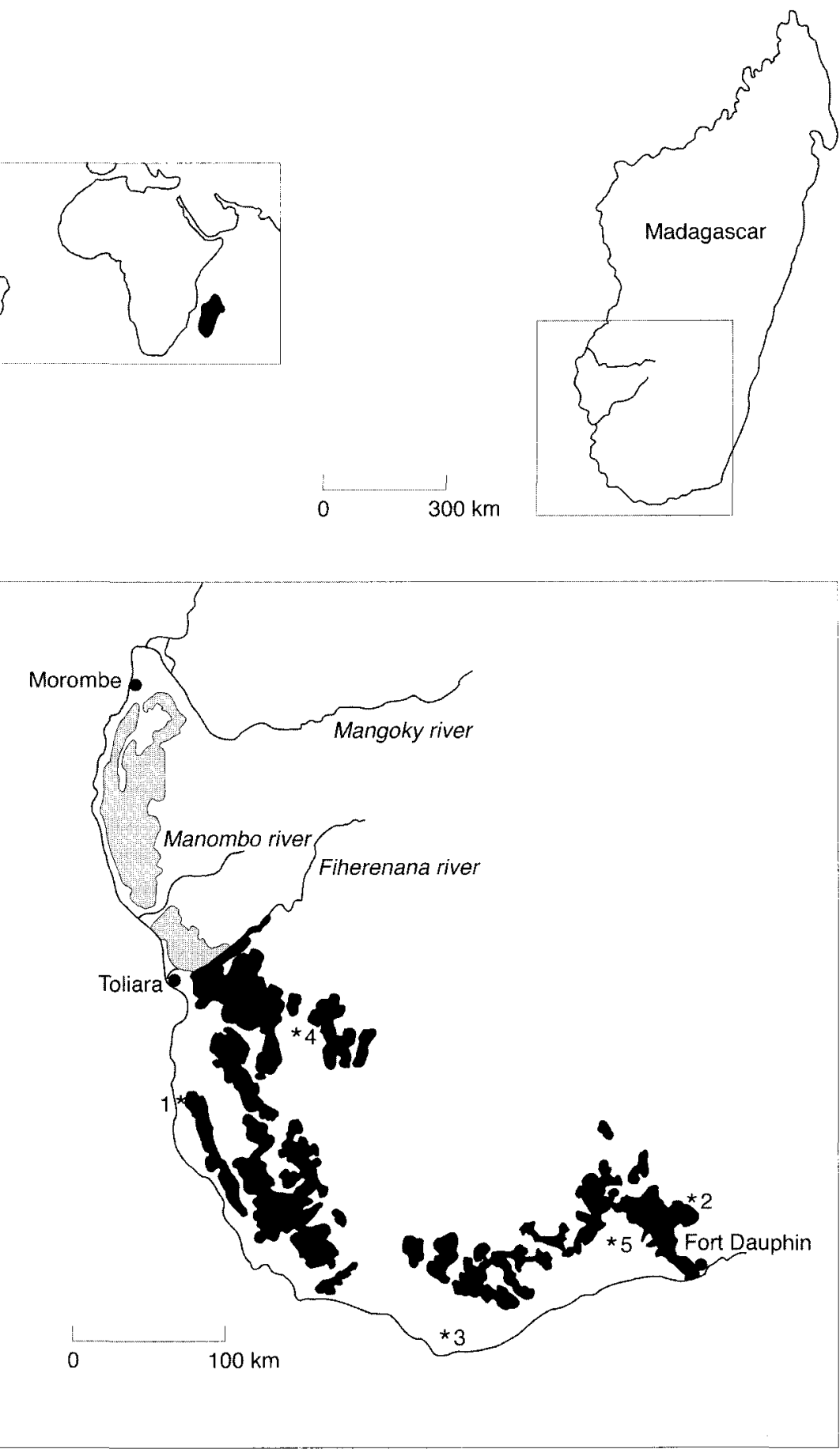

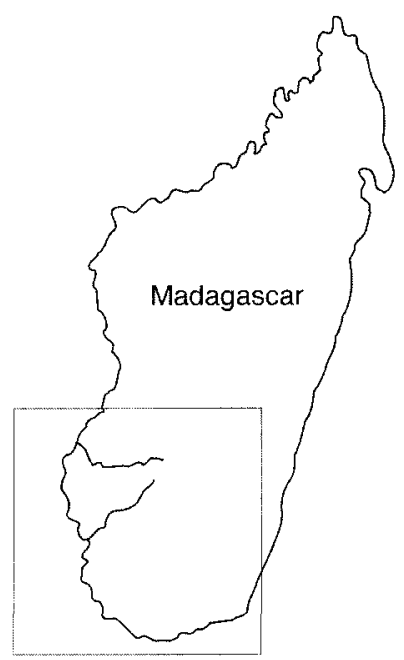

Fig. 1 (a) Location of Madagascar relative to the African mainland, and (b) distribution of the Mikea Forest (grey) and the Southern Dry Forests (black) in south-west Madagascar. The protected areas are: 1. Réserve

Naturelle Intégrale de

Tsimanampetsotsa, 2. Parc National d'Andohahela, 3. Réserve Speciale de Cap St Marie, 4. Réserve Speciale de Beza Mahafaly, and 5. Réserve Privée de Berenty. 


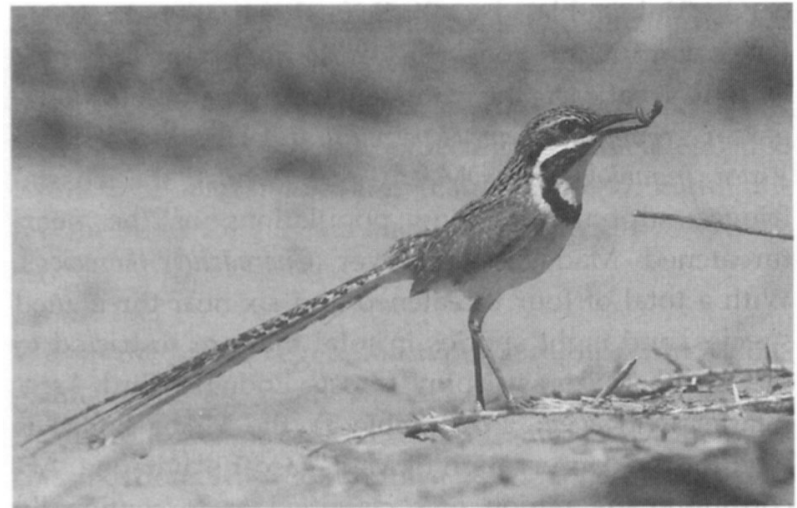

Plate 1 Long-tailed ground-roller with food for young, PK32, December 1998 (Joe Tobias).

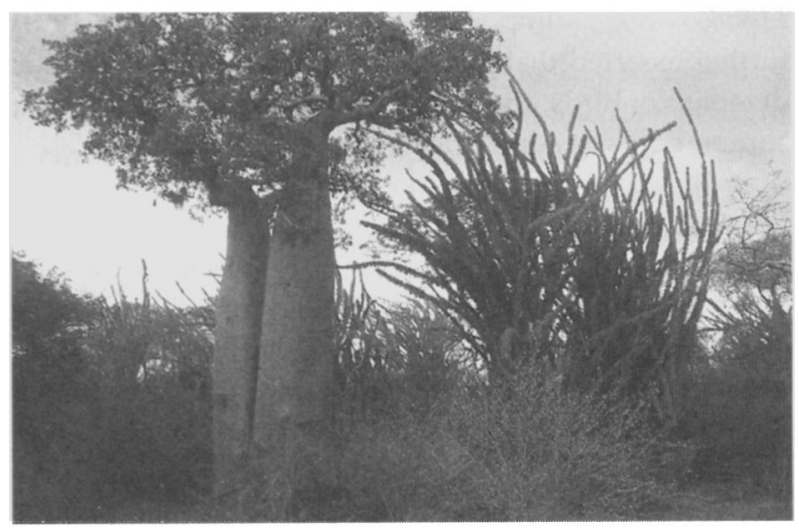

Plate 2 Characteristic dry forest tree flora: Didierea madagascarinsis (back right) and Adansonia fonty (left) (Stuart Butchart).

present the results of two such studies carried out in 1997-2000. We highlight the biodiversity value of the Mikea Forest, present approximate estimates of forest cover from satellite imagery taken around 1962 and 1994, and estimate current forest cover on the basis of field surveys and imagery taken in 1999. We give an account of relevant threats, describe areas where conservation attention would best be focused and discuss the potential structure of conservation programmes. Our aim is to stimulate discussion and action among parties interested in, or capable of contributing to, the long-term protection of wildlife and habitat in the area.

\section{Background}

\section{Regional biogeography}

The Mikea Forest is thought to have originally formed a coastal strip $30-60 \mathrm{~km}$ wide and $200 \mathrm{~km}$ long between the Fiherenana and Mangoky rivers at 0 $200 \mathrm{~m}$ a.s.l. (Fig. 1). The climate is dry, tropical and stochastic with $100-1300 \mathrm{~mm}$ of rainfall per annum, over 85 per cent of which falls between November and March (in 1999, mean $\pm \mathrm{SE}=780 \pm 91 \mathrm{~mm}$, range $=$ $490-1267 \mathrm{~mm}, n=9$ rain gauges located in the northern Mikea Forest between Vorehe and Ankindranoka; B. Tucker, pers. comm., 2000). This contrasts with the c. $350 \mathrm{~mm}$ per annum in the Southern Dry Forests (recorded for Reserve Spéciale de Cap St Marie; ZICOMA, 1999). Rainfall increases northwards and eastwards, a factor that, along with the heterogeneous geology (Du Puy \& Moat, 1996), may be largely responsible for variations in vegetation structure found along this axis. The mean annual temperature is $26^{\circ} \mathrm{C}$, with a peak of $42{ }^{\circ} \mathrm{C}$ in December (Salomon, 1987). The soils generally consist of unconsolidated sands, with fine white sands predominating in the coastal plain, and red sands rich in sesquioxides predominating inland towards the calcareous plateau that delimits the eastern boundary of the forest (Salomon, 1977). The sandy substrate of the Mikea Forest distinguishes it edaphically from the Southern Dry Forests to the south, which occur principally on a limestone plateau (Du Puy \& Moat, 1996).

The vegetation forms a complex mosaic but largely comprises a dense, highly xerophytic flora attaining a maximum height of $6 \mathrm{~m}$ towards the coast and 8-12 m further inland. This flora is characterized by succulent and spinescent plants, most notably the endemic family Didiereaceae (in particular Didierea madagascariensis; see Plate 2). The tree flora additionally includes woody euphorbias (e.g. Euphorbia stenoclada near the coast and Euphorbia laro inland), baobabs (chiefly Adansonia fony, but also Adansonia $z a$ in some areas; see Plate 2), and several species in the genus Commiphora. Other conspicuous tree species of the upper stratum are Givotia madagascariensis, Delonix adansonioides, Pachypodium spp. and Dalbergia tricolor. The mid and lower strata are dominated by a variety of lianas, commonly Diospyros spp. and an exceptionally high diversity of Euphorbiaceae and leguminous plants. Within $2 \mathrm{~km}$ of the coast the vegetation becomes more sparse and scrub-like and E. stenoclada and Aloe divaricata dominate. North-west of Antseva, c. $300 \mathrm{sq} \mathrm{km}$ of forest is distinguished from the rest of the Mikea Forest by its greater stature (10-12 m) and the presence of flora common to the dry western forests north of Morombe (e.g. Hildegardia spp., Commiphora mafaidoha, and Adansonia za; Réau, 1996; Razanaka, 1996).

There are, in addition, several wetland areas within the Mikea Forest. Two of the most important are the saline Lake Ihotry, Madagascar's second largest wetland, in the north $\left(21^{\circ} 80^{\prime} \mathrm{S}, 43^{\circ} 40^{\prime} \mathrm{E}\right)$, and the freshwater Lake Andranobe in the south $\left(23^{\circ} 03^{\prime} \mathrm{S}, 43^{\circ} 37^{\prime} \mathrm{E}\right)$. There are other (largely seasonal) smaller areas of wetland in 
the Namonty basin to the west of Lake Ihotry, and in the forests north of Manombo.

Faramalala $(1988,1995)$ and Inventaire Ecologique Forestier National (IEFN) (1997) classify both the Mikea Forest and Southern Dry Forests as dense dry forest or xerophytic scrub. However, the floristic compositions of these two areas differ considerably (Phillipson, 1996; Razanaka, 1996). One such difference is that whilst the dominant species of Didiereaceae in the Mikea Forest is Didierea madagascariensis, in the Southern Dry Forests this species is largely replaced by Alluaudia ascendens and $A$. procera (see Rakotovao et al., 1996).

\section{Socio-cultural context}

The region is populated largely by people who classify themselves in three separate, though flexible, groupings: Vezo, Mikea and Masikoro. The coastal fringes are inhabited by the Vezo, a people whose cultural identity and economy are largely based on harvesting marine wildlife. While they practise some cultivation and livestock rearing along forest edges, they primarily exchange fresh or dry fish, crustaceans and molluscs for agricultural products (Astuti, 1995). Inland areas south of the Manombo river and east of the Mikea Forest are inhabited by the Masikoro: farmers and cattle herders. Between the coast and the inland savanna lies the Mikea Forest, an area traditionally inhabited by the Mikea. The Mikea are predominantly Masikoro and Vezo in origin, although their identity is complex and flexible (Yount et al., in press). They are mainly characterized by a forest lifestyle involving the hunting of wildlife (e.g. birds, lemurs, tenrecs) and gathering of fruit, tubers and moisture-bearing plants. However, all Mikea communities participate extensively in non-foraging activities including livestock-rearing and agriculture, and currently their diet is dominated by maize and manioc (B. Tucker, pers. comm., 1999). In addition to these three groups, there are significant numbers of Tandroy and Mahafaly immigrants from the south who practise mainly hatsake (slash-and-burn maize cultivation) throughout the region, particularly in areas of dense red sands (Réau, 1996).

\section{The biological importance of the Mikea Forest}

\section{Birds}

A total of 98 bird species (45 breeding) have been recorded in this region's forests and wetlands, of which 40 are endemic to Madagascar (ZICOMA, 1999). While this total is relatively modest, it includes the subdesert mesite and long-tailed ground-roller, two monotypic genera restricted entirely to the Mikea Forest (Stattersfield et al., 1998), that have been classified as threat- ened (Vulnerable) by BirdLife International (2000). Lakes within the zone (the most important of which is Ihotry) attract the threatened (Vulnerable) Madagascar grebe Tachybaptus pelzelnii and Humblot's heron Ardea humbloti (ZICOMA, 1999), whilst the coastal fringes support breeding populations of the nearthreatened Madagascar plover Charadrius thoracicus. With a total of four threatened and six near-threatened species, and eight species in total that are restricted to the 'South Malagasy spiny forests Endemic Bird Area' (Stattersfield et al., 1998; Table 1), the Mikea Forest is vital for the conservation of Madagascar's avifauna. Accordingly, the region was classified as exceptionally important' for bird conservation by Ganzhorn et al. (1997), while ZICOMA (1999) identified both Lake Ihotry (in conjunction with the Mangoky delta) and the Mikea Forest as Important Bird Areas. ZICOMA (1999) further asserted that in terms of preserving the 'genetic diversity of birds, the Mikea Forest will be considered a supreme priority in Africa'.

\section{Reptiles}

The Mikea Forest harbours a rich reptile fauna: a total of 49 species have been recorded (Raxworthy, 1995). This figure is comparable to the highest found in other western forests (e.g. in the Bemaraha and Namoroka Reserves, Morondava region) and makes the area one of the more diverse for reptiles in Madagascar ( $C$. Raxworthy, pers. comm., 1999). In addition to four threatened species (Table 1), the region harbours many extremely poorly known and locally endemic reptiles including a chameleon Chamaeleo belalandaensis (only known from a few individuals recorded between the Fiherenana and Manombo rivers), true skinks (e.g. Voeltzkowia petiti from the littoral dune systems), a snake (Liophidium chabaudi) and geckos (e.g. Phyllodactylus brevipes and a recently discovered new species Paroedura sp. nov.; Raxworthy, 1995). Owing to the presence of such rare animals, the preservation of the southern Mikea Forest (PK32 area) has been deemed essential (Raxworthy, 1995). Whilst further work is required throughout the region, the Mikea Forest is clearly important for reptiles.

\section{Mammals}

The diversity of mammals in the Mikea Forest has been described as 'moderate' (Garbutt, 1999). Three threatened species are known to occur in the Mikea Forest (Table 1) although none are limited to this habitat and none are common in the area because of high hunting pressure. As no published mammal surveys have been conducted in the Mikea Forest, it is difficult to assess its importance for this group. Further research may reveal the existence of mammals of conservation significance 
and is considered a 'very high' priority (Ganzhorn $e t$ al. 1997). In December 1998, we recorded a Lepilemur sp. resembling the white-footed sportive lemur Lepilemur lewcopus, rather than the expected red-tailed sportive lemur Lepilenur ruficaudatus (Garbutt, 1999), highlighting the need for further mammal surveys.

Plants

Within the broad vegetation types recognized in Madagascar, there are many distinct plant communities but owing to a lack of basic research there is no systematic classification at a community level (WWF \& IUCN, 1994). Nonetheless, sufficient data are available to identify south and south-west Madagascar (the 'southern domain'; White, 1983) as having the highest plant endemism of all domains in Madagascar (WWF \& IUCN, 1994; Phillipson, 1996). Within this domain, tree and shrub endemism is greatest within the dry forests $(61.4$ versus 28.3 per cent for riverine forest and 20.8 per cent for wooded grassland; Phillipson, 1996). Few published data are available for the Mikea Forest although high levels of plant endemism are to be expected given the variation in geology and climate within the region, the presence of wetlands and of transitional zones supporting species from the western forests. Certainly, Ganzhorn ot al. (1997) describe the botanical importance of the Mikea Forest north of the Manombo as 'very high', and that north of Toliara as 'exceptionally high'. They further identify the entire forest as a 'very high' priority for botanical research.

\section{Methods}

In addition to the studies of Domergue (1983), Raxworthy (1995), Razanaka (1995, 1996), Réau (1996) and CNRE (2000) we gathered information during three 6-month field seasons (1997-2000). We compiled inventories of birds, plants and reptiles at two forest sites south of the Manombo river (Fig. 1): Mangily $\left(23^{\circ} 07^{\prime} 00 \mathrm{~S}, 4^{\circ} 37^{\prime} 40 \mathrm{E}, 120 \mathrm{ha}\right)$ and PK32 (23 $04^{\prime} 80 \mathrm{~S}$, $43^{\circ} 37^{\prime} 25 \mathrm{E}, 200 \mathrm{ha}$ ), and these form the basis of our habitat description and biodiversity assessment. Furthermore, we carried out semi-structured interviews with local people from within and around these sites to

Table 1 Species of conservation concern in the Mikea Forest

\begin{tabular}{|c|c|c|c|c|}
\hline Group & Species & English name & Status* & Threat codes \\
\hline \multirow[t]{16}{*}{ Birds } & Tachybaptus pelzelnit & Madagascar grebe & $\mathrm{V}$ & \multirow[t]{2}{*}{$\mathrm{A} 2 c, \mathrm{e} ; \mathrm{C} 1 ; \mathrm{C} 2 \mathrm{~b}$} \\
\hline & Ardeola idaet & Madagascar pond-heron & NT & \\
\hline & Ardea humblotit & Humblot's heron & $\mathrm{V}$ & \multirow[t]{5}{*}{$\mathrm{C} 2 \mathrm{~b}$} \\
\hline & Lophotibis cristata & Madagascar crested ibis & NT & \\
\hline & Phoeniconaias minor $\dagger$ & Lesser flamingo & NT & \\
\hline & Accipiter madagascariensis & Madagascar sparrowhawk & NT & \\
\hline & Accipiter henstii & Henst's goshawk & NT & \\
\hline & Monias benschit & Subdesert mesite & $V, R R$ & \multirow[t]{3}{*}{$\mathrm{A} 2 \mathrm{c}, \mathrm{d} ; \mathrm{B} 1+2 \mathrm{c}, \mathrm{e}$} \\
\hline & Charadrius thoracicus $\S$ & Madagascar plover & NT & \\
\hline & Couta cursor & Running coua & lc, RR & \\
\hline & Uratelornis chimaera $\ddagger$ & Long-tailed ground-roller & $\mathrm{V}, \mathrm{RR}$ & \multirow[t]{6}{*}{$\mathrm{A} 2 \mathrm{c} ; \mathrm{B} 1+2 \mathrm{c}, \mathrm{e} ; \mathrm{C} 1$} \\
\hline & Xenopirostris xenopirostris & Lafresnaye's vanga & lc, RR & \\
\hline & Monticola imerinus $\S$ & Littoral rock-thrush & lc, RR & \\
\hline & Nesillas lantzii & Subdesert brush-warbler & NE, RR & \\
\hline & Thamnornis chloropetoides & Thamnornis warbler & lc, RR & \\
\hline & Newotonia archboldi & Archbold's newtonia & Ic, RR & \\
\hline \multicolumn{5}{|l|}{ Mammals } \\
\hline Carnivores & Cryptoprocta ferox & Fosa & $\mathrm{V}$ & $\mathrm{B} 1+2 \mathrm{e}$ \\
\hline \multirow[t]{2}{*}{ Primates } & Lemur catta & Ring-tailed lemur & $\mathrm{V}$ & A1c \\
\hline & Propithecus verreauxi & Verreaux's sifaka & $\mathrm{V}$ & $\mathrm{A} 2 \mathrm{c}, \mathrm{d}$ \\
\hline \multicolumn{5}{|l|}{ Reptiles } \\
\hline Geckos & Phelsuma standingi & & $\mathrm{V}$ & $\mathrm{A} 1 \mathrm{c}, \mathrm{d}$ \\
\hline Snakes & Boa dumerili & Madagascar boa & & $A 1 c, d$ \\
\hline \multirow[t]{2}{*}{ Tortoises } & Geochelone radiata & Radiated tortoise & $\mathrm{V}$ & $\mathrm{Ala}, \mathrm{c}, \mathrm{d}, 2 \mathrm{c}, \mathrm{d} ; \mathrm{B} 1+2 \mathrm{a}, \mathrm{b}, \mathrm{c}$ \\
\hline & Pyxis arachnoides & Spider tortoise & $\mathrm{V}$ & $\mathrm{B} 1+2 \mathrm{a}, \mathrm{b}, \mathrm{c}, \mathrm{d}$ \\
\hline
\end{tabular}

* Status and threat codes follow BirdLife International (2000) for birds, and IUCN (1996) for mammals and reptiles. $\mathrm{V}$, vulnerable; NT, near-threatened; $\mathrm{lc}$, least concern; NE, not evaluated; RR, restricted-range $(<50,000 \mathrm{sq} \mathrm{km}$; Stattersfield et al., 1998).

+ Species occurring in wetland areas within forest, i.e. Ihotry and/or Andranobe lakes.

$\ddagger$ Species restricted to undisturbed coastal scrub and dry forest interior.

$\S$ Species restricted to littoral zone. 


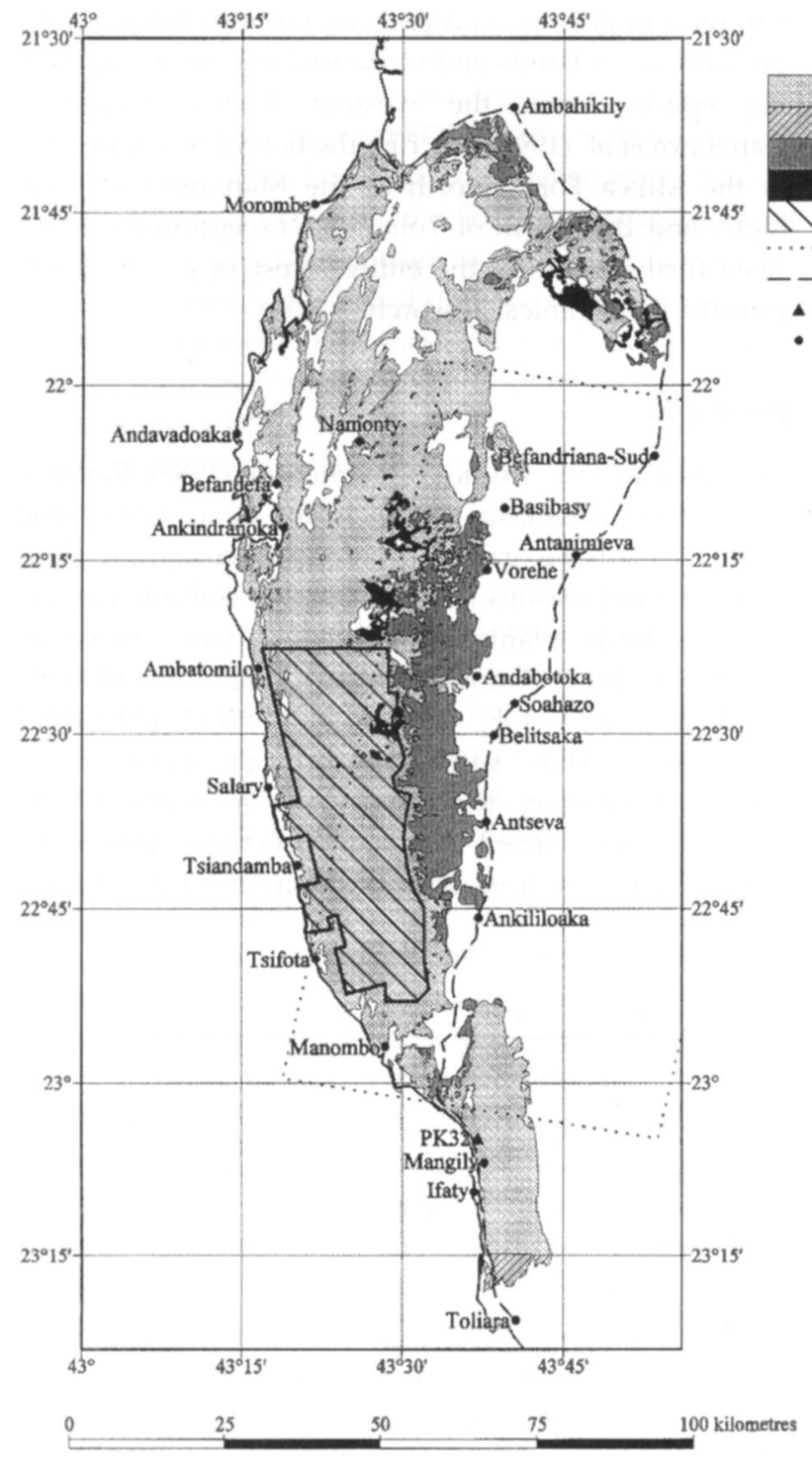

gather information on threats, approximate rates of forest loss and the socio-economic importance of forest resources. During the course of investigating the status and distribution of the long-tailed ground-roller and subdesert mesite, we conducted two linear transects across the Mikea Forest in January 1999 and eight linear transects in November 1999: PK32 (c. 20 km, November); Tsifota-Ankililoaka (c. $20 \mathrm{~km}$, January and November); Tsiandamba-Antseva (c. $25 \mathrm{~km}$, January and November); Salary-Belitsaka (c. $25 \mathrm{~km}$, November); Ambatomilo-Andabotoka (c. $25 \mathrm{~km}$, November); Ambatomilo-Befandefa (c. $10 \mathrm{~km}$, November); Ankindranoka-Basibasy (c. $20 \mathrm{~km}$, November); east of Morombe (c. $10 \mathrm{~km}$, November). Along the c. $200 \mathrm{~km}$ of these transects, we recorded coordinates at regular intervals with a GPS (Garmin 2 Plus), mapped basic soil and vegetation characteristics and recorded evidence of
Legend

Intact and degraded forest, 1994 Intact and degraded forest, 1985 Deforestation, 1962-1994/99 Regeneration since 1962 1999 \$POT image extents RN9: National Highway $\$$ 9 PK32: Kilometer Marker \#32

Village Proposed core protected area
Fig. 2 Approximate extent of total dry forest cover, regeneration, and deforestation in the Mikea Forest in 1962, 1994 and 1999. The proposed location of a core protected area is also illustrated (James Yount). human disturbance (e.g. cultivation, charcoal production, livestock rearing). In 1998-2000, J.W.Y. gathered data on human causes and impacts of deforestation in the Mikea Forest using both traditional ethnographic methods, rapid rural appraisal (Freudenberger, 1994), and in-field interpretation of aerial photos and satellite imagery.

Maps of forest cover (Fig. 2) and vegetation types (Fig. 3) were developed from a 1962 declassified US surveillance satellite photo (Argon mission 9034A, 18 05/62), a 1994 Landsat TM satellite image provided by the Inventaire Ecologique Forestier National (IEFN), 1997 of the Ministère des Eaux et Forets (MEF), and two 1999 SPOT satellite images (03120723-36587 and -28090) provided by Projet Sud-Ouest. Images were interpreted using ISODATA automatic classification in conjunction with field reference data gathered during 1998-2000 
and maps were prepared (by J.W.Y.) using TNT maps GIS software. Natural spatial variations in forest density and, in many instances, gradual transitions between vegetation types rendered vegetation mapping more difficult and less precise. Furthermore, the low quality of the 1962 image made the deforestation analysis less accurate. Fieldwork attenuated some of these problems, and we estimate each spatial measurement to be within 5 per cent of the actual value. We emphasize that our aim is not to present absolute figures for the extent of each habitat type. Rather, it is to provide the best possible estimate of change in total forest cover in 1962-94, and 1994-99. A more precise study of forest types in the region, and their changing distribution, is currently being undertaken (by J.W.Y.) in collaboration with WWF and the Missouri Botanical Garden.

Nomenclature and taxonomy follow Dowsett \& Forbes-Watson (1993) for birds (with recent modifications following Morris \& Hawkins, 1998), Wilson \& Reeder (1993) for mammals, Glaw \& Vences (1994) for reptiles and the Royal Botanical Gardens, Kew (1997) for plants.

\section{Change in forest cover}

In 1960, the area of dry forest (i.e. Mikea and Southern Dry Forests combined) was estimated to cover approximately 29,000 sq km (Guichon, 1960). Estimates of remaining forest cover based on 1990 satellite imagery range between 14,000 and $17,000 \mathrm{sq} \mathrm{km}$ (Nelson \& Horning, 1993; Du Puy \& Moat, 1996), which suggests a decline of 41-51 per cent in 30 years.

Focusing exclusively on the Mikea Forest, we continue to estimate high rates of forest loss (Fig. 2, Table 2). Between 1962 and 1999, we estimate an overall decline in primary forest cover of 15.5 per cent, the majority ( $>90$ per cent of deforestation occurring west of Route Nationale 9 (RN9) between Ankililoaka and Vorehe. However, during this time there was also some regrowth (c. $116 \mathrm{sq} \mathrm{km}$ ); therefore, we estimate overall forest cover to have declined by around 12.8 per cent.

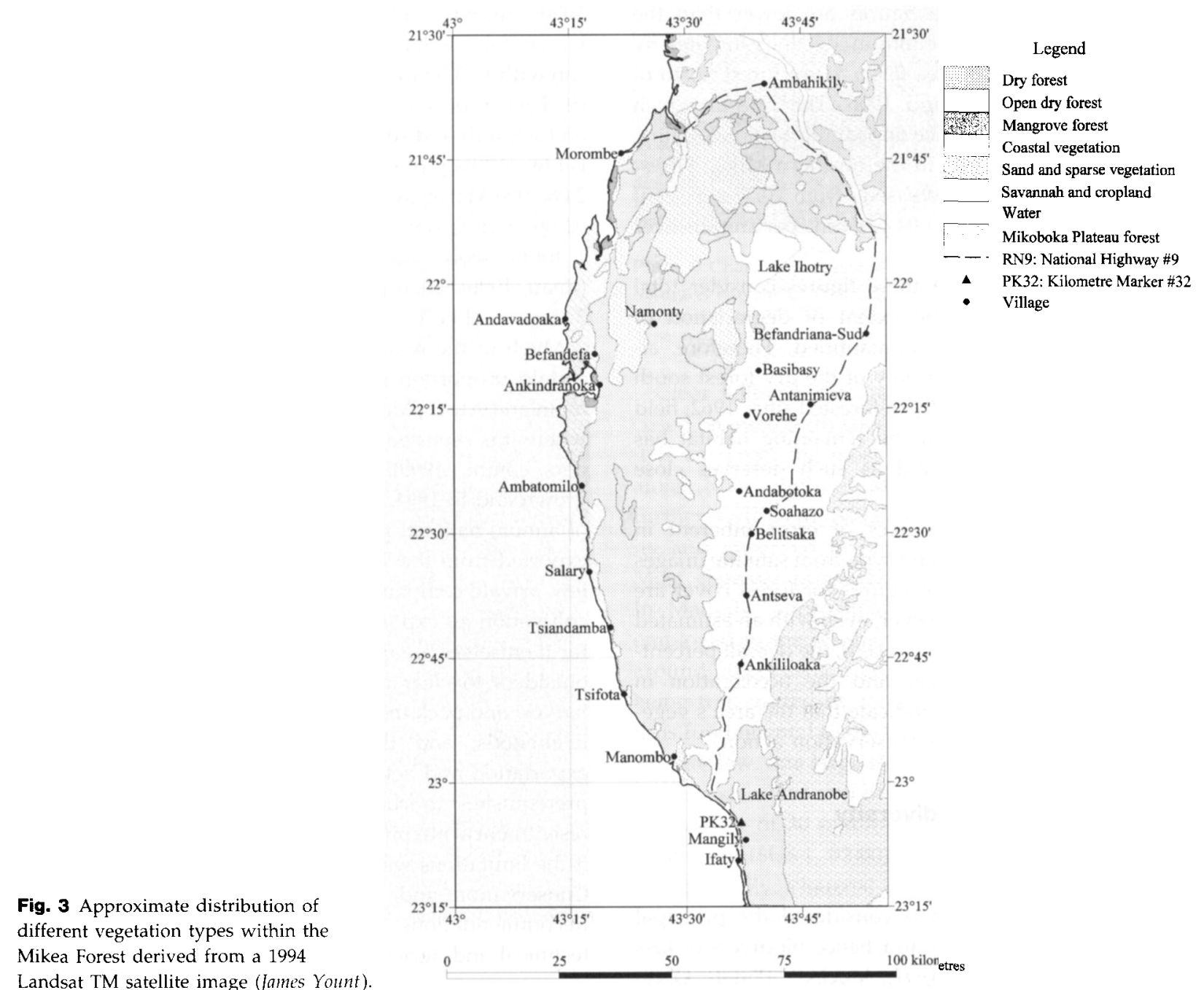


Table 2 Extent of forest cover, regrowth and rate of deforestation in the Mikea Forest in 1962-1999

\begin{tabular}{|c|c|c|c|c|c|c|c|c|}
\hline & \multicolumn{3}{|c|}{ Forest cover (sq km) } & \multirow{2}{*}{$\begin{array}{l}\text { Decline in } \\
\text { overall forest } \\
\text { cover }(\%) \\
1962-99\end{array}$} & \multirow{2}{*}{$\begin{array}{l}\text { Regrowth } \\
(\mathrm{sq} \mathrm{km}) \\
1962-94\end{array}$} & \multicolumn{2}{|c|}{$\begin{array}{l}\text { Rate of deforestation } \\
\text { (\% per anum) }\end{array}$} & \multirow{2}{*}{$\begin{array}{l}\text { Decline in } \\
\text { primary forest } \\
\text { cover }(\%) \\
1962-99\end{array}$} \\
\hline & 1962 & 1994 & $1999+$ & & & $1962-94$ & $1994-99$ & \\
\hline $\begin{array}{l}\text { Northern Mikea Forest } \\
\text { (Manombo-Morombe) }\end{array}$ & 3787 & 3449 & 3269 & 13.7 & 116 & 0.37 & 1.04 & 16.7 \\
\hline Southern Mikea Forest ${ }^{*}$ & 465 & 438 & 437 & 6.0 & 0 & 0.18 & 0.05 & 6.0 \\
\hline Overallt & 4252 & 3887 & 3706 & 12.8 & 116 & 0.35 & 0.93 & 15.6 \\
\hline Restricted areał & 1915 & 1618 & 1437 & 25.0 & 60 & 0.58 & 2.24 & 28.1 \\
\hline
\end{tabular}

* Measurements were taken from between the coast and the eastern plateau, and from the Manombo river south to $23^{\circ} 15^{\prime} \mathrm{S}$.

+ Assumes no deforestation between 1994 and 1999 outside the area covered by the 1999 SPOT image; cover estimates should, therefore, be considered minimum values.

$\ddagger$ Figures relate only to that portion of the forest covered by the 1999 SPOT image (Fig. 2).

These figures undoubtedly represent an underestimate of the total forest decline during this period because it is assumed that there was no deforestation other than that occurring in the area covered by the 1999 SPOT images (Fig. 2). Focusing only on this region, we estimate a decline in overall forest cover of 25.0 per cent $(0.68$ per cent per annum) and in primary cover of 28.1 per cent from 1962 to 1999 . These figures are lower than the 23 per cent ( 2.3 per cent per annum) decline estimated by Réau (1996) for a small area (8726 ha) of forest north of Belitsaka between 1986 and 1996. The rate at which deforestation is taking place appears to be accelerating, this being especially true in the northern Mikea Forest where the rate has increased from 0.37 per cent per annum in 1962-94 to 1.04 per cent per annum over the past 5 years.

It should be noted that these figures consider total deforestation only and the extent of degradation of remaining forest remains unquantified. Therefore, although around 6.0 per cent only of the dry forest south of Manombo has been totally deforested since 1962, field observations indicated that the remaining habitat has been severely degraded and as such deserves close monitoring.

Given the numerous sources of error inherent in mapping vegetation cover and type from satellite images and field data, the absolute figures for forest cover are likely to be inaccurate. However, even with an estimated margin of error of around 5 per cent, the overall percentage decline in forest cover and the acceleration in deforestation rate strongly indicate that the area's vegetation warrants immediate conservation action.

\section{Current threats to biodiversity}

Maize cultivation

Slash-and-burn cultivation is considered the principal agent of forest destruction and hence biodiversity loss in Madagascar (WCMC, 1991; ANGAP, PNUE, ONE,
1998). This is certainly true in the north and central regions of the Mikea Forest. Here, hatsake (slash-andburn maize cultivation, Plate 3 ) is carried out on land technically owned by the government but which has been occupied by the Mikea for more than 100 years (Yount et al., in press). Although Mikea have been cultivating maize in the Mikea Forest since at least the 1950s, recent Tandroy migrants now tend to cultivate larger areas: 10 ha per household per annum in comparison with 1-3 ha for local Mikea and Masikoro households (B. Tucker, pers. comm., 2000). Hatsake is most common on the sandy red soils to the east, although productivity is low: a 2-ha plot yields 8 tonnes of grain worth around 2,080,000 Malagasy Francs (MGF; equivalent to \$US 320, $02 / 00$ ) in its first year, but by the fifth year only produces 1 tonne worth around 260,000 MGF (\$US 40, 0200 ) (Réau, 1996). Such plots are generally abandoned after 3-5 years (J.W.Y., pers. obs.).

Much of the maize is consumed locally. However, a certain proportion is reportedly destined for export to mainland Africa, Mauritius, Réunion, and the Seychelles, where it is reportedly used for animal feed (B. Forgeau, pers. comm., 1999). Since 1990, demand for maize has grown and in 1994, 11,300 tonnes of maize ( 7.3 per cent of annual national production in 1994; IMF, 1999) were exported from the Toliara region alone (Réau, 1996). A few private companies based in Toliara promote maize cultivation for export. In addition to those who cultivate for themselves, people are employed by both locals and outsiders to clear and burn the forest, and to grow, harvest and pack the maize. The provision of alternative livelihoods, and the tighter control of commercial exportation and activities of immigrant cultivators are prerequisites to conserving the Mikea Forest. Initial resentment at attempts to limit hatsake might be mitigated if the limitations were imposed as part of an Integrated Conservation and Development Project (ICDP) (see Recommendations for conservation) incorporating technical and agricultural developments. 


\section{Charcoal production}

The vast majority (c. 95 per cent) of Madagascar's 15.06 million inhabitants (FAO, 1998) depend on wood and charcoal for domestic use (Goodman et al., 1997). Although Malagasy households are generally economical in their use of fuel, 'the current capacity for charcoal production from plantations falls short of meeting the needs of the island over the next decade' (Richard \& O'Connor, 1997). Charcoal production, which targets all tree species except those of low fibre density (e.g. Adansonia spp. and Delonix adansonioides), is increasing in intensity: from 1996-98 national wood fuel production increased by 5.8 per cent (FAO, 1998). The proportion of national charcoal production coming from the dry forests is probably small in terms of both biomass and calorific value compared to that coming from the rest of Madagascar. However, given the lower standing biomass, exploitation in dry forests is likely to have a proportionately greater impact on native vegetation, and clearance for charcoal has been identified as the 'principal threat to the (Mikea Forest) region' (Langrand, 1990).

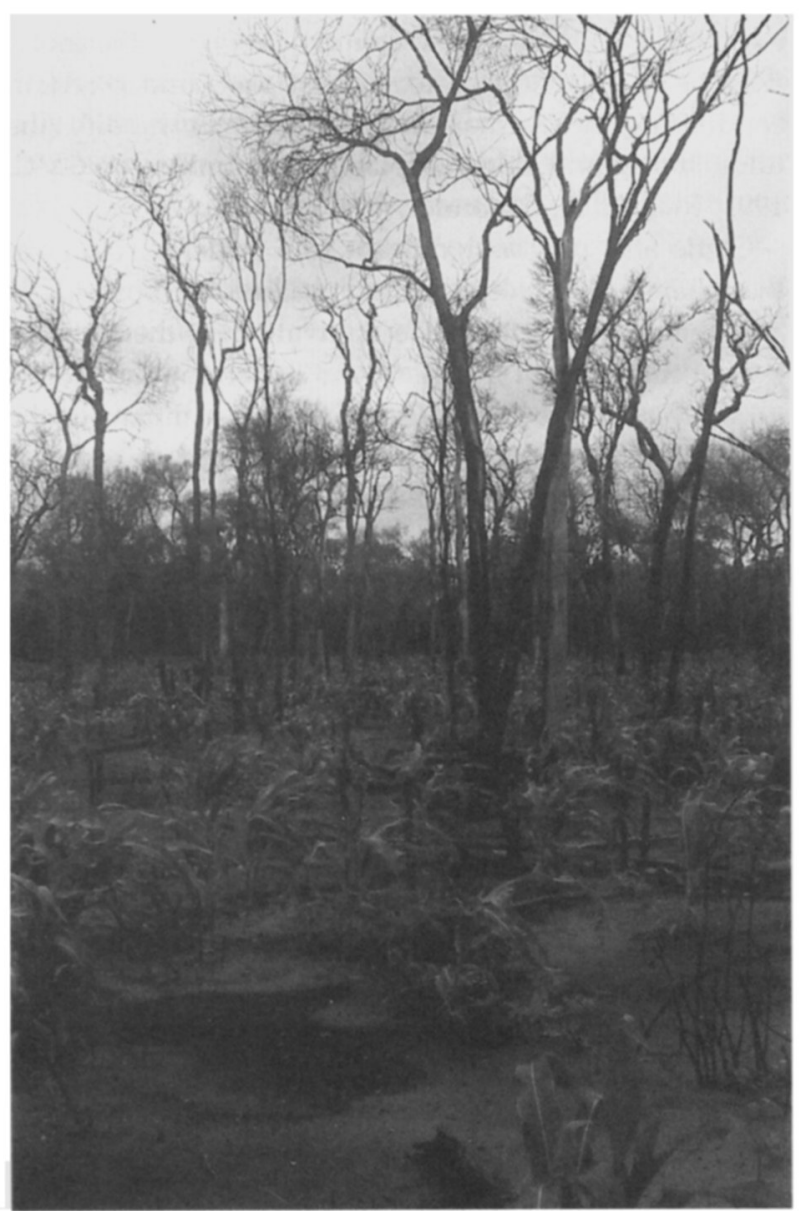

Plate 3 Hatsake (slash-and-burn maize cultivation) west of Antseva, January 1999 (Joe Tobias).

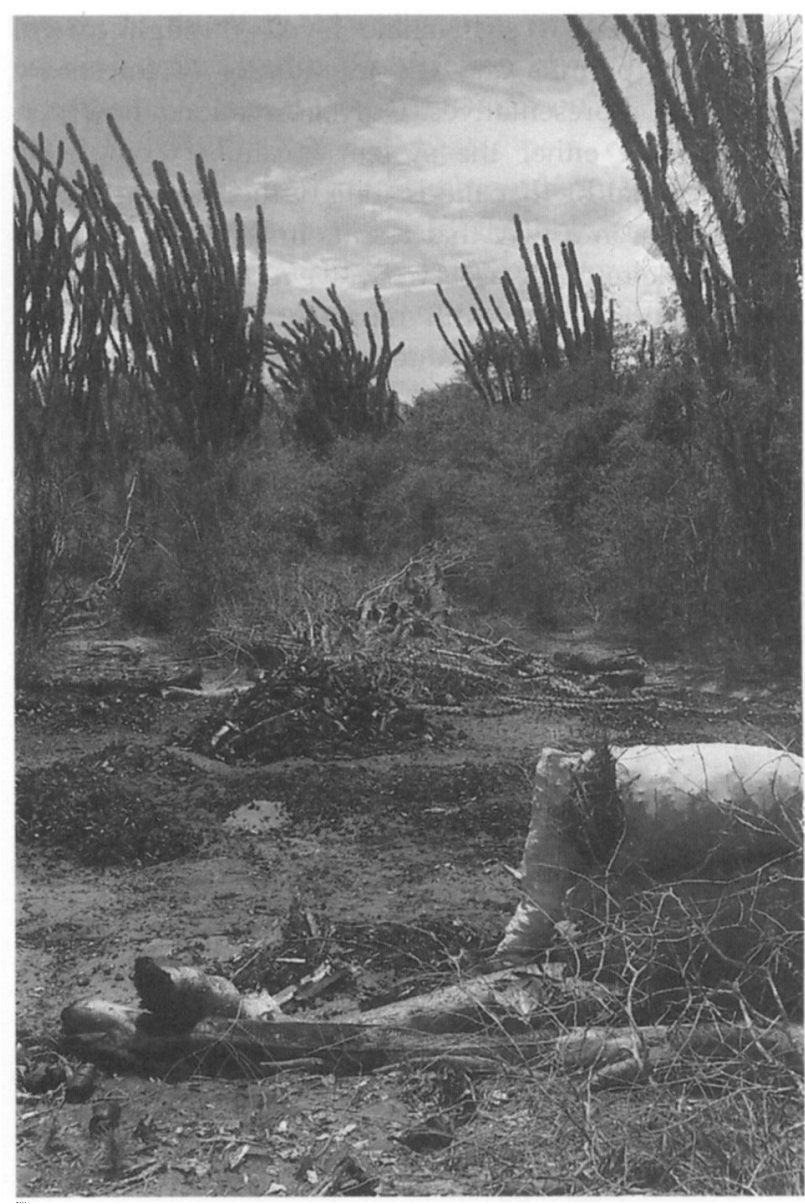

Plate 4 Charcoal production in degraded forest north of Mangily, November 1998 (Nathalie Seddon).

Clear felling for charcoal production (Plate 4) is focused on areas with adequate road infrastructure. While it is currently the most serious cause of deforestation along RN9 south of Manombo, fuelwood extraction further north in the Mikea Forest is limited by accessibility and governed by the daily needs of local people. Most charcoal production is carried out by Masikoro. In Mangily, approximately 40 per cent of people are employed in the production of charcoal, of which only around 30 per cent is consumed locally, the remainder being transported by road to Toliara. While charcoal is thus fundamental to the local economy, its market value is quite low: one large rice sack (weighing $100 \mathrm{~kg}$ when full, the standard unit of measure in this case), entailing an average of 30 mature trees equates to around 6500 MGF only (\$US 1, 02/00).

Technically, charcoal production is controlled by a licensing system enforced by the government body, the Ministère des Eaux et Forets (MEF). In theory, charcoal production in unprotected government forests should 
be maintained at sustainable levels through careful issuing of permits and the monitoring of forests by local MEF representatives. Our observations, however, suggest that either the system is almost completely dysfunctional or that the issuing authorities are granting permits in a way that results in excessive and unsustainable resource use. Firstly, we received unsubstantiated reports of local MEF representatives actively taking part in charcoal production at PK32. Secondly, in November 1997 to January 2000, the number of charcoal pits at this site increased from 17 to 30 per sq km, representing a loss of at least 400 mature trees in less than 3 years. This rate of exploitation is likely to be unsustainable, given the slow rates of regeneration by dry forests in general (Deleporte et al., 1996) and our observations that in 3 years there were minimal signs of regrowth in areas burnt for charcoal production.

\section{Local construction materials}

Our observations indicated that in the southern Mikea Forest, certain settlements are growing rapidly following the increase in tourism and migration of people from the south. We estimated that the number of dwellings in the Ifaty-Mangily area had increased by 40 per cent between September 1997 and January 2000. Such an increase places intense demands on adjacent forest for construction materials. For example, for each $4 \times 4 \mathrm{~m}$ dwelling, which lasts $3-5$ years only, at least nine trees $(\mathrm{dbh}>10 \mathrm{~cm}$ ) and 350 saplings (dbh $<2 \mathrm{~cm}$ ) of more than five species are used (including Commiphora spp., Cedrelopsis grevei, and Khaya madagascariensis). In addition, each house or small compound of houses is inefficiently delimited by fences made of saplings, commonly including hundreds of individual trees. The growth in local population has also increased the demand for Givotia madagascariensis, a tree used to construct sailing canoes. These also tend to last 35 years only, and are sold for between 250,000 and 700,000 MGF (\$US 40-110). Baobabs (Adansonia spp.) are also felled for roofing materials, and very occasionally for rope and a source of moisture for cattle by the Masikoro. Clearance of forest for the provision of construction materials is also a threat in the north, near Morombe. However, it appears to be a less serious threat in the central part of the Mikea Forest where the human population density is lower.

\section{Commercial timber extraction}

Most commercial timber extraction is conducted illegally in Madagascar (e.g. c. 80 per cent in Morondava; Raonintsoa, 1996), and is usually limited to areas with adequate road infrastructure. South of Manombo, ex- traction is increasing steadily and we noted that virtually all large trees have already been removed from the western edge within $1-2 \mathrm{~km}$ of RN9. A worrying development in 1999 was the arrival of regular trucks in the PK32 area to collect large quantities of timber destined for Toliara. To the north, several commercial loggers began exploiting wood between Manombo and Antanimieva in the late 1990s, and extraction along the southern banks of the Mangoky has been accelerating over the past decade (B. Forgeau, pers. comm., 2000).

\section{Livestock grazing}

From 1990 to 1999 the number of goats and cattle kept in Madagascar increased by 12 and 3 per cent, respectively, with the majority (c. 61 per cent) being restricted to the south and west coasts (Rasambainarivo \& Razafindratsita, 1998). Goats and cattle are grazed throughout the Mikea Forest, a factor that may affect regeneration, although research is needed to confirm this. Certainly, burning for pasture in abandoned maize fields eliminates forest regeneration, at least on forest edges (M. Grouzis, pers. comm., 2000). Furthermore, there is some evidence to suggest that, under certain conditions, the animals may themselves modify the understorey and damage plant communities (WCMC, 1991; Richard \& O'Connor, 1997).

Cattle also play a significant role in deforestation in that their acquisition is highly valued by both locals and immigrants and maize cultivation in the forest is perceived as one of the best ways of earning the money to purchase more cattle. Cattle theft is rampant in the Mikea Forest area (J.W.Y., pers. ob.), and is reported locally to have increased over the last two decades. This leads not only to the impoverishment of the local population but may also be a motivation for further deforestation to replace the cattle lost

\section{Wildlife trade}

Most of the wildlife trade in Madagascar involves birds, plants and especially reptiles: for example, in 1985, well over 1000 individuals of each of six day gecko species Phelsuma spp. were exported illegally (WCMC, 1991). At PK32, mixed foreign and Malagasy teams made collections of two threatened reptiles: Phelsuma standingi and radiated tortoise Geochelone radiata, in addition to the skink Zonosaurus quadrilineatus, and the endemic plant Pachypodium geayi, all of which are listed in Appendix II of CITES and are therefore illegal to export. Whilst we only recorded this activity in December 1999, it was locally reported to occur at least annually with the wildlife destined for both private and 
public zoo collections in Europe and the USA (B. Forgeau, pers. comm., 2000). Such collecting has been held responsible for the local extinction of Phelsuma standing $i$ in many areas of the southern Mikea Forest close to RN9 (Raxworthy, 1995).

\section{Tourism}

In 1994-98, the number of tourists visiting Madagascar increased by 103 per cent to 133,500 per annum, with both hotel capacity and tourist revenue doubling during this period (IMF, 1999). Some of this tourism targets the Mikea Forest, in particular the villages of Ifaty and Mangily north of Toliara, although growing numbers of tourists are visiting the Morombe area. Year-round hotel occupation in the region averages 45 per cent, with numbers of visitors estimated at 5000-8000 per annum (WWF, 1993). A 5-fold increase in tourist revenue was recorded from 1985 to 1993 (WWF, 1993) and although no more recent data are available, the Mikea Forest is likely to have received further increases given recent rises in national tourist revenue. There is potential for further growth on two main accounts. First, in comparison with other regions in Madagascar, the infrastructure is relatively well developed and is gradually being improved. Second, the area has numerous important attractions. The reef, which extends along the coastline and supports a diverse marine life, constitutes a significant lure and many hotels already cater for divers and snorkellers. The forest itself has great scenic value mainly as a result of the presence of baobabs. The forest also attracts numbers of specialist bird tour companies (five in 1999) and bird watchers seeking the mesites and ground-rollers. Finally, the Mikea people themselves attract a significant number of tourists and journalists. Owing to the lack of examples elsewhere where tourism has had positive effects on traditional cultures, we have serious reservations about the wisdom of this latter trend (King \& Stewart, 1996).

The potential of tourism to provide a viable economic alternative for local people, as well as revenue for the sustainable protection of natural resources, has long been recognized but remains contentious (Boo, 1990; King \& Stewart, 1996). Indeed, tourism in the Mikea Forest has promoted some local informal protection of reefs and has generated income for some villagers (WWF, 1993). Nevertheless, it currently has more deleterious than beneficial effects. For example, we discovered that between Toliara and Manombo most of the coastal scrub immediately adjacent to the road (RN9) has been privately purchased or burned off to assert ownership by immigrants planning to build hotels. The increased demand for charcoal and building materials has precipitated the degradation of much adjacent forest. In the Ifaty-Mangily area, major decreases in water supplies and a proliferation of sex-tourism and disease have been blamed by some on the growth of tourism (WWF, 1993; B. Forgeau, pers. comm., 1999). Further, cultural tourism in the northern Mikea Forest has deepened rifts between local ethnic groups in the Mikea Forest, by causing jealousy, exaggerating folklore and propagating myths about the Mikea, strengthening the local view that they are strange and inferior.

Tourism in the Mikea Forest has thus far failed to create incentives for conservation because cash benefits accrue to a tiny minority of hotel management and staff, most of whom originate from outside the region. A prerequisite to solving current problems is the commitment of people whose livelihood ultimately relies upon good relationships with the local communities and a relatively intact natural habitat. Hotel management could train local people as staff and guides, and arrange for some of the tourist revenue to be redistributed towards protection of local forest, reefs, and ideally towards the improvement of local water supplies and schools.

One way of organizing such activities would be to develop tourism as a major component of an ICDP (see below) as in Botswana and Namibia (Jones, 1997). In this way, tourism can 'contribute to secure livelihoods, generate significant local earnings, and stimulate local participation and empowerment' (Ashley \& Roe, 1998). In Namibia, capacity-building and institutional support have been crucial, with communities negotiating with the private sector and receiving support from local, national and international NGOs. On this basis, they have formed their own organization, the Namibia Community Based Tourism Association (NACOBTA; Jones, 1997; Ashley, 1997). An approach modelled on this successful example may work in the Mikea Forest. Such a scheme could harness the presently wasted potential of ecotourism, transforming it from a threat into a conservation tool.

Whilst the human pressures on the Mikea Forest have previously been described as 'fair' (Ganzhorn et al., 1997), we report that forest cover has already diminished in extent and continues to be threatened by many human activities. The influence of these practices varies: slash-and-burn maize cultivation is the principal agent of destruction in the north and central regions, while charcoal production is the most serious threat in the south. Rates of deforestation through slash-andburn maize cultivation may decline as all suitable land is utilized. The other threats, however, will almost certainly intensify as the local human population continues to grow through immigration from other regions and at an estimated natural rate of 3.0 percent for Madagascar overall (IMF, 1999). 


\section{Conservation measures taken}

In the Mikea Forest, no areas are effectively protected by law (ANGAP, PNUE, ONE 1998), although both the forest at PK32 and Lake Ihotry were classified as Sites d'Intérêts Biologiques (SIBs), with the southern portion of the latter being designated a hunting reserve (Réserve de Chasse) in 1972 (Nicoll \& Langrand, 1989). However, whilst highlighting the importance of these areas for future conservation action, SIB status confers no official protection and indeed habitat degradation at PK32 has continued apace.

In contrast, five legally protected areas have been established in the Southern Dry Forests (Fig. 1), encompassing 2 percent of the total dry forest thought to remain (Du Puy \& Moat, 1996). For definitions of protected area classification see ANGAP, PNUE, ONE (1998). Table 3 lists the endangered fauna recorded in these reserves, and the fauna present in a large potential protected area in the Mikea Forest.

\section{Recommendations for conservation}

It is clear that conservation action is needed urgently to protect the Mikea Forest. However, the conservation situation is complex and various socio-political and biological issues merit careful consideration before any action is instigated. Recognizing that conservation remains an experimental endeavour, that flexibility is essential and that human needs must also be addressed, we urge that a combination of approaches be considered. Specifically, we recommend: (1) the establishment of a large core protected area; (2) a network of locally-managed conservation areas; (3) parallel development efforts to improve agriculture and human conditions; and (4) a regional research and education centre.

\section{(1) Core protected area}

From the perspective of conserving biodiversity in the long term we believe that a protected area, properly managed, could be an important component of an overall conservation strategy for the Mikea Forest. This protected area should encompass as large an area of forest as possible in order to protect viable populations of rare, locally endemic and threatened species. It should incorporate the littoral zone, coastal scrub, dry forest and a marine portion, given the vulnerability and biological importance of the offshore reef (A. Cooke, pers. comm., 1999). There are two cases that set a precedent for this in Madagascar: Parc National de Mananara-Nord and Parc National de Masoala.

Such an area would best be sited north of Manombo, this being the most intact and least populated area of habitat encompassing a range of pristine dry forest types, intact coastal scrub and small areas of wetland. The core of the protected area should be delimited by the settlements Tsiandamba, Ambatomilo, Ankililoaka and Andabotoka (Fig. 2) and be located where climax forest survives on a low plateau (50 $\mathrm{m}$ a.s.1., $22^{\circ} 40^{\prime} \mathrm{S}, 43^{\circ} 25^{\prime} \mathrm{E}$ ). The western and northern edges, and the western portion of the southern edge, are defined by petroleum research roads established early in the 1960s. These roads provide a clear demarcation on the ground and are commonly used as territorial limits between local communities. The eastern limit of this proposed core protected area comes within $c .1 \mathrm{~km}$ of the current forest edge. As large an area as possible of the eastern part of the forest must be incorporated into the core area, the vegetation there being the most threatened. The precise boundaries must be determined through negotiation with the local population. The area north-east of Tsifota is excluded from the proposed core area because the village is already exploring the possibility of locally protecting a traditionally sacred seasonal wetland found there.

The official types of protected areas in Madagascar are continuing to evolve and include new and proposed categories with greater flexibility for management approaches (M. Nicoll, pers. comm., 2000). The possibility of provincial rather than national parks has also been suggested (M. Fenn, pers. comm., 2000) and is consistent with the current trend of decentralized responsibility. The precise institutional nature of the proposed protected area must be determined by the Malagasy people.

Ecotourism, channelled through Toliara, could target such an area, and the employment of local people as guards and guides would help to provide alternative livelihoods for a small proportion of the community. Indeed, despite the assertion by Wells \& Brandon (1992) that it is 'extremely rare for a (tourist) revenue share to go to local people', Durbin \& Ratrimoarisaona (1996) found that in Madagascar the allocation of protected area entrance fees to local development projects is proving beneficial. However, they also found that tourist revenue was inadequate to fund park management, confirming that the establishment and maintenance of such a park would have to be financed through other means.

\section{(2) A network of locally-managed conservation areas}

Most of the forest between Toliara and Manombo is highly degraded and the region is densely populated. This is also the case in the forest north of Lake Ihotry and near Morombe. Scattered smaller subsistence settlements are also found throughout the forest from 


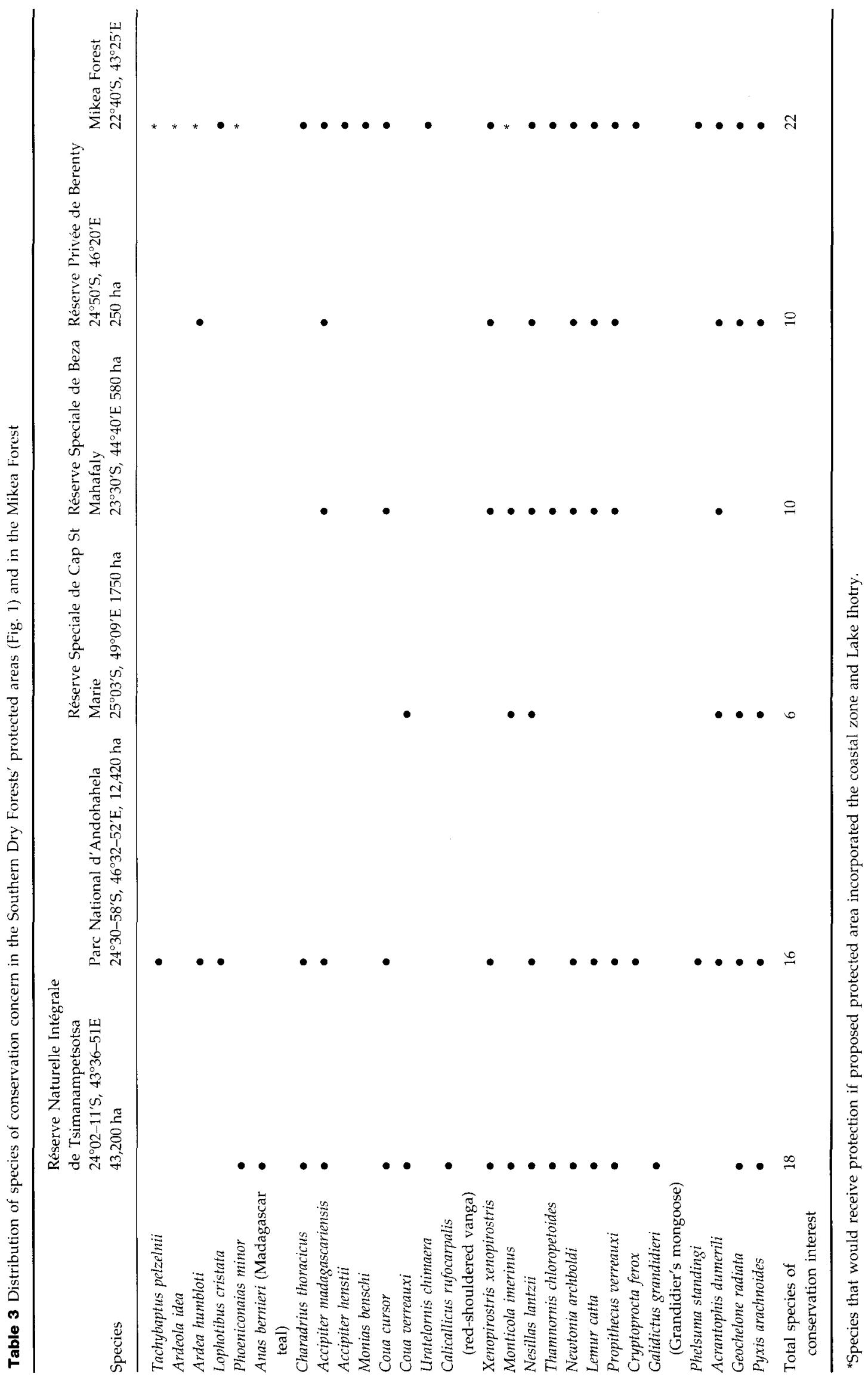

(1) $2000 \mathrm{FFI}$, Oryx, 34(4), 287-304 
Namonty south to the northern limit of the proposed core protected area. These areas are less suitable as traditional protected areas both as a result of historical community claims to the land and to the consequently greater human impact, which this history of occupation implies. Furthermore, the Mikea communities are likely to reject externally imposed conservation measures, given their long history of mistrust, resentment and resistance to external oppression (Yount et al., in press). These areas are still important, however, for conservation of biodiversity and their management is also essential to the long-term viability of the communities that live there. Community-based conservation initiatives are, therefore, the preferred strategy in this area.

Indeed, we agree with Durbin \& Ralambo (1994) that 'local participation in conservation plans is more likely to enhance their quality and produce the sought-after results'. Failure to involve village elders and incorporate the local political structure in conservation planning at Ranomafana National Park led to serious difficulties in the establishment of an ICDP (Wright, 1997).

Much criticism has been levelled at ICDPs in Madagascar in recent years (e.g. Sussman et al., 1994), largely owing to the lack of clear evidence for effective biodiversity conservation. Amongst the main problems are the weak enforcement of the laws protecting forest, a low awareness and understanding amongst local people of conservation issues, and a high cost of compliance for local communities (Richard \& O'Connor, 1997). Furthermore, "the inclusion of communities in the rule-making and enforcement process is no guarantee of successful resource conservation given that social and economic contexts also matter' (Horning, 2000). However, as emphasized by Wells \& Brandon (1992), ICDPs are 'complex experiments trying to achieve different goals' and insufficient time has passed to judge the success of the projects (Richard \& O'Connor, 1997). While there is no established recipe for success, the integration of conservation and development as an operating principle is clearly the only way to both alleviate social problems and protect the environment.

A new approach to conservation by the Government of Madagascar is GELOSE (Géstion Locale Sécurisée), which involves the negotiation of local management and resource use within and between local stake-holding communities and the national government. Once agreement is reached, local management is backed by national law, which theoretically enhances the local community's capacity to defend their resources against outside interests, including loggers and those seeking land for slashand-burn agriculture, charcoal production, cattle herding or development. Greater local control in theory leads to a more long-term perspective in resource use: an experiment worth pursuing when the alternative status quo is ongoing degradation. The approach is hoped to be both more ethical and ultimately more sustainable, but it is too early at this stage to evaluate its effectiveness. L'Association pour le Sauvegarde de l'Environnement began initial negotiations for GELOSE projects in the Mikea Forest region in December 1999, the results of which are not yet known.

One priority area for GELOSE-style conservation is the forest north of PK32 bordering Lake Andranobe, an area long-considered a conservation priority (Domergue, 1983; Raxworthy, 1995). In 1999, the inhabitants of the settlements around the lake expressed a commitment to long-term preservation of the forest, and the village president is currently compiling a proposal for forest protection for presentation to MEF in Toliara. Several other communities have expressed a similar interest, including Tsifota and villages near Lake Ihotry (J. Bond, pers. comm., 1999) and Morombe. Several of these areas also have a high tourist potential within reach of an existing tourism infrastructure. Should community-based conservation projects be established, we recommend regular monitoring following criteria such as those set out by Richard \& O'Connor (1997), with opportunities to adapt if current strategies are not meeting stated goals. Indeed, as indicated in a recent study in south-west Madagascar, consistent monitoring and sanctioning are likely to encourage compliance with rules governing forest use by local people (Horning, 2000).

GELOSE focuses on a very small regional scale encompassing one or several village territories. To play an effective role in an overall strategy for the entire Mikea Forest, local conservation and development efforts need to be integrated in a regional network. FiMAMi, the Association for the Protection of the Mikea Forest, is a non-governmental organization established in 1998 with precisely this goal in mind. The Comité Régional de Programmation (CRP) in turn facilitates communication and exchanges between FiMAMi and similar organizations recently established throughout southern Madagascar as part of the same general effort to democratize conservation and development. WWF's Dry Forest Ecoregion Project collaborates with the CRP to develop a comprehensive long-term ecoregion-based conservation plan for the dry forests between Morombe and Fort Dauphin. Any conservation efforts in the Mikea Forest should seek collaboration with these projects.

\section{(3) Improving agriculture and human conditions}

Large areas of the northern Mikea Forest are being lost to extensive maize cultivation because although the yield is low, relatively little effort is required. Improvements in non-destructive agricultural practices are clearly required. Several different organizations (e.g. 
Projet Sud-Ouest (PSO) and the Association Nationale des Actions Environnementales) are developing and promoting 'zero-till' agriculture on the grasslands and abandoned fields east of the forest. This technique involves a method of cultivation whereby soils are never tilled and new crops are planted amongst legumes and or grasses that have been knocked over rather than cut down. The simplicity of zero-till is comparable with slash-and-burn (L. Seguy, pers. comm., 2000), and it promises high yields and low labour requirements while actually improving the soil (Rollin \& Razafintsalama, 1998). Every effort should, therefore, be made to promote the use of this technique throughout the northern Mikea Forest.

We additionally recommend the following suite of initiatives, which could be implemented in conjunction with development organizations currently operating in the area (e.g. PSO, Fonds d' Intervention et Developpement and Aide et Action).

- Development of more efficient charcoal and wood stoves.

- Provision of alternative energy sources. Whilst plantations are an obvious alternative source of energy, they are unlikey to work in this region because trees grow extremely slowly in infertile soils (60-120 years for restoration between cuts, Deleporte et al., 1996), and the human and financial capital needed for such a long wait is unlikely to be available' (Richard \& O'Connor, 1997). However, solar power could become important given that the region experiences c. 350 days of sunshine per annum and bio-gas could be generated, the British Embassy having donated funds for the construction of a demonstration bio-gas installation near Ifaty (WWF, 1993). Although the provision of alternative energy is of crucial importance, given the substantial. logistical, cultural and financial constraints, much research is required before it is practicable in the long term. Such research could be carried out in conjunction with the WWF's sustainable energy project, which was established in 1996 to investigate the problems of energy supply and consumption in the Toliara region (WWF, 1997).

- Instigation of village-based education programmes aimed at demonstrating the economic and energetic benefits of alternative energy sources and crops, and their compatibility with local traditions.

- Improvements in the design of local housing and fencing so as to increase structural life-span and reduce requirements for construction materials.

- Improved animal husbandry techniques, including apiculture.

- Development of dry forest agroforestry.

- Development of cultivation, semi-cultivation and sustainable commercial harvesting of wild tubers, honey and other non-endangered wild forest products. - Re-establishment of a wild-silk harvesting industry, apparently devastated by anti-locust pesticides.

- Development of cultivation or sustainable harvest of natural plant medicines.

These initiatives should be integrated with other conservation measures and should be developed in collaboration with local populations, who will ultimately determine which techniques are adopted and how.

(4) Regional research, education and monitoring centre Wright (1997) recommends the establishment of highquality long-term biodiversity research stations in at least five different biogeographic regions in Madagascar. We endorse the establishment of such a centre in the Mikea Forest, preferably in conjunction with the University of Toliara. Although there are existing centres in the Southern Dry Forests (the Libanona Ecological Centre in Fort Dauphin, and the research centre at Beza-Mahafaly), we feel that the ecology and socio-politics of the Mikea Forest are significantly different and warrant the establishment of a further research and monitoring centre. Malagasy and foreign students could undertake research on issues such as the ecology of endemic animal and plant species, including the monitoring of abundance and health of target species, the impact of livestock rearing, forest regeneration following clearance, etc. Data gathered during such research projects should be donated to the National Biodiversity Database managed by ANGAP to assist decision-making at a local or national government level.

There should be a strong training component with local people being educated in agro-ecology, taxonomy, epidemiology and sensitive, informed tourist guiding, as in Ranomafana National Park where, in addition to the local guides, over 30 local people are research assistants (Wright, 1997). University students could benefit simultaneously from local knowledge regarding the natural environment and there should be work aimed at integrating scientific and indigenous knowledge into a plan for sustained yield of forest products.

One of the most important potential contributions of such a centre should be the ongoing monitoring and evaluation of conservation and development efforts in the region. This could include analysis of the barriers to promising innovations such as zero-till agriculture, solar cooking and the identification of necessary adaptations or locally meaningful messages for use in their social marketing.

Given the experimental nature of conservation and development efforts in general, as well as an everchanging context, the specific initial approach may ultimately be less important than ongoing monitoring and adaptation. The regional centre proposed here could be 
a focal point to evaluate impacts holistically, identify problems and suggest solutions in this particular experiment. Its ultimate effectiveness would depend upon establishing collaboration between local communities, government bodies and educational institutions.

\section{Conclusions}

The dry forests of south and south-west Madagascar are under-represented in current conservation programmes despite their outstanding biodiversity value. For this reason, they have been identified as the area in Madagascar with the greatest need for additional conservation efforts (Du Puy \& Moat, 1996). We endorse this view, but point out that within this large biogeographic region the Mikea Forest is unique, effectively unprotected and is showing signs of rapid degradation. Conservation action in this particular area is therefore of utmost importance. We strongly recommend a combination of a core protected area, a coordinated network of smaller community-based conservation areas, integrated parallel developments focusing on agriculture, and the establishment of a regional research, education and monitoring centre. As a result of the experimental nature of any conservation and development efforts, however, flexibility and ongoing adaptation will be central to long-term success.

\section{Acknowledgements}

We are grateful to the Ministère des Eaux et Forets for granting us permission to conduct our research, and to the Parc Botanique et Zoologique de Tsimbazaza, Projet ZICOMA, the Missouri Botanical Garden, the Centre de Documentation et de Recherche sur l'Art et les Traditions Orales à Madagascar (CeDRATOM) of the University of Toliara and Projet Sud-Ouest for their support of the project. Our sincere thanks also go to Gary Allport, Bernard Bouvier, Joanna Durbin, Mark Fenn, Lincoln Fishpool, Bob Kelly, Lin Poyer, Odon Rakotonomjanahary, Andry Vahatriniaina Rabemanantsoa, Bertrand Réau, Flavien Rebara, Zafitompo Rengoky, Tsiazonera, Jaovola Tombo and Bram Tucker. We are particularly indebted to Bernard Forgeau for his unwavering logistical support and for sharing his knowledge of the area. Finally, James Bond, Andrew Cooke, Frank Hawkins and three anonymous referees generously provided comments that greatly improved this paper.

\section{References}

ANGAP, PNUE, ONE (1998) Monographie Nationale sur la Biodiversité. L'Association Nationale pour la Gestion des
Aires Protégées, Antananarivo, Madagascar [in French]. Ashley, C. (1997) Livelihood Strategies of Rural Houscholds in Caprivi: 'Implications for Conservation and Natural Resonrce Management. Living in a Finite Environment (LIFE) Programme of WWF and USAID, Windhoek, Namibia.

Ashley, C. \& Roe, D. (1998) Enhancing Community Involvement in Wildife Tourism: Issues and Challenges. International Institute for Environment and Development, London.

Astuti, R. (1995) People of the Sea. Descent and Identity among the Vezo of Madagascar. Cambridge University Press, Cambridge, UK.

BirdLife International (2000) Threatened Birds of the World. BirdLife International, Cambridge, UK.

Boo, E. (1990) Ecotourism: the Potentials and Pitfalls. WWF, Baltimore.

CNRE (2000) Sociétés paysannes, dynamiques écologique's et gestion de l'espace rural dans le sud-outest de Madagascar. Atelier Centre Nationale de Recherche Enviromenental, 8-10 Novenbre. Antananarivo, Madagascar [in French].

Collar, N.J \& Stuart, S.N. (1988) Key Forests for Threatene't Birds in Africa. BirdLife International, Cambridge, UK.

Curry-Lindahl, K. (1975) Man in Madagascar. Defenders of Wildife, 50, 164-169.

Deleporte, P., Randrianasolo, J. \& Rakotonirina (1996) Sylviculture in the dry forest of western Madagascar. In Ecology and Economy of a Tropical Dry Forest in Madagnscar (eds J.U. Ganzhorn and J.-P. Sorg), pp. 89-116. Erich Goltze, Göttingen, Germany.

Domergue, C.A. (1983) Note préliminaire en vue de la mise en réserve de la forêt du point kilomètre 32 au nord de Tuléar Madagascar [in French]. Bulletin de l'Academie Malgache, 61, 105-114.

Dowsett, R.J. \& Forbes-Watson, A.D. (1993) Checklist of Birds of the Afrotropical and Malagasy Regions. Tauraco Press, Liège, Belgium.

Du Puy, D. J. \& Moat, J. (1996) A refined classification of the primary vegetation of Madagascar based on the underlying geology: using GIS to maps its distribution and to assess its conservation status. Biogéographie de Madagascar, 1996, 205-218.

Durbin, J.C. \& Ralambo, J.A. (1994) The role of local people in the successful maintenance of protected areas in Madagascar. Environmental Conservation, 21, 115-120.

Durbin, J.C. \& Ratrimoarisaona, S.-N. (1996) Can ecotourism make a major contribution to the conservation of protected areas in Madagascar? Biodizersity and Conservation, 5, 345-353.

FAO (1998) Statistical database. In Food and Agricultural Organisation-Production Yearbook. FAO, Rome.

Faramalala, M.H. (1988) Etude de la végétation de Madagascar à l'aide des données spatiales. PhD thesis, Université Paul Sabatier de Toulouse, $167 \mathrm{pp}$. + map at 1:1,000,000 [in French].

Faramalala, M.H. (1995) Formations Végétales êt Domaine Forestier National de Madagascar. Conservation International, Antananarivo, Madagascar [in French].

Freudenberger, K.S. (1994) Tree and Land Tenure: Rapid Appraisal Tools. Community Forestry Field Manual No. 4. Rome, FAO. 
Ganzhorn, J., Rakotosamimanana, B., Hannah, L., Hough, J., Iyer, L., Olivieri, S., Rajaobelina, Rodstrom, C. \& Tilkin, G. (1997) Prioritics for conscration in Madagascar, Primate Report 48-1. Special Issue.

Garbutt, N. (1999) Mammals of Madogascar. Pica Press, Sussex, UK.

Glaw, F. \& Vences, M. (1994) A Field Guide to the Amphibians and Reptile's of Midtagascar. Moos Druck, Leverkusen, Germany.

Goodman, S.M., Pidgeon, M., Hawkins, A.F.A. \& Schulenberg, T.S. (1997) The birds of southeastern Madagascar. Ficldiana, 87, 1-132.

Guichon, A. (1960) La superficie des formations forestières à Madagascar. Revule Forestière Française, 6, 408-411 [in French].

Horning, N.R. (2000) Explaining compliance with rules governing common-pool forest resource use and conservation: dynamics in Bara country, southwestern Madagascar. Procedings of the International Association for the Study of Common Property, 31 May-4 June 2000, Bloomington, Indiana.

IMF (1999) Madagascar: Statistical Amtex. International Monetry Fund Staff Country Report no. 99/17. IMF Publication Services, Washington, DC.

Inventaire Ecologique Forestier National (1997) Carte de la Végétation de Madagascar, 1:1,000,000. FTM, Antananarivo, Madagascar [in French].

IUCN (1996) IUCN Red List of Threatented Animals. IUCN, Gland, Switzerland.

Jones, B. (1997) Community-based Nature Resource Management in Botsutata and Namibian Inventory and Preliminary analysis of Progress. Report to the International Institute for Environment and Development, Evaluating Eden Project.

King, D.A. \& Stewart, W.P. (1996) Ecotourism and commodification: protecting people and places. Biodiversity and Conservation, 5, 293-305.

Langrand, O (1990) Guide to the Birds of Madagascar. Yale University Press, New Haven and London.

Morris, P. \& Hawkins, F. (1998) Birds of Madagascar. A Photographic Guide. Pica Press, East Sussex, UK.

Nelson, R. \& Horning, N. (1993) AVHRR-LAC estimates of forest area in Madagascar, 1990. International Journal of Remote Sensing, 14, 1463-1475.

Nicoll, M.E. \& Langrand, O. (1989) Madagascar: Revue de la Conservation et des Aires Protégées. WWF, Gland, Switzerland [in French].

Phillipson, P.B. (1996) Endemism and non-endemism in Madagascar. Biogéographie de Madagascar, 1996, 125-136.

Rakotovao, L.H., Rajeriarison, C. \& Ramavololona (1996) Les Didiereaceae: origine, affinités systématiques et répartition à Madagascar. Biogéographie de Madagascar, 1996, 183 [in French].

Raonintsoa, P.N. (1996) The role of the forest in the local economy. In Ecology and Economy of a Tropical Dry Forest in Madagascar Primate Report 46-1 (eds J. U. Ganzhorn and J. P. Sorg), pp. 41-47. Göttingen, Germany.

Rasambainarivo, J.H. \& Razafindratsita, R. (1998) Production of the Malagasy extensive livestock. In Food and Agricultural Organisation-Production Yearbook 1998. FAO, Rome.
Raxworthy, C. (1995) Field Survey of Amphibians, Reptiles and Small Mammals from the Toliara Region, Madagascar, October 5-30 1995. Unpublished field report, University of Michigan, USA..

Razanaka, S.J. (1995) Délimitation des zones de contact déserts semi aride et sub aride de la végétation du Sud-Ouest de Madagascar. Thèse de Doctorat 3ème cycle, Université d'Antananarivo, $244 \mathrm{pp}$ [in French].

Razanaka, S.J. (1996) Répartition des espèces xérophiles dans le sud-ouest de Madagascar. Biogéographie de Madagascar, 1996, 171 [in French].

Réau, B. (1996) Dégradation de l'environnement forestier et reactions paysannes: les migrants tandroy sur la côte ouest de Madagascar. PhD thesis, Université Michel de Montagne, Bordeaux, France [in French].

Richard, A. \& O'Connor, S. (1997) Degradation, transformation and conservation. In Natural Change and Human Impact in Madagascar (eds S.M. Goodman and B.D. Patterson). Smithsonian Institute Press, Washington, DC.

Rollin, D. \& Razafintsalama, H. (1998) Du semis direct en agriculture extensive sur défriche au semis direct sur une couverture permanente du sol, éléments pour une évolution des systèmes de culture dans le Sud-ouest. In Actes de l'atelier International sur la Gestion Agrobiologique des Sols et des Systèmes de Culture, 23-28 Mars [in French]. Antsirabe, Madagascar.

Royal Botanical Gardens and Kew (1997) Index Kewensis. Version 2, CD-ROM Oxford University Press, Oxford.

Salomon, J.N. (1977) Fourrés et forêts sèches du Sud-ouest Malgache. Madngascar Revue Géographie, 32, 19 [in French].

Salomon, J.N. (1987) Le Sud-ouest de Madagascar, Étude de Géographie Physique. Presses Universitaires Bordeaux, Bordeaux, $998 \mathrm{pp}$ [in French].

Stattersfield, A.J., Crosby, M.J., Long, A.J. \& Wege, D.C. (1998) Global Directory of Endemic Bird Areas, BirdLife International (BirdLife Conservation Series). BirdLife International, Cambridge, UK.

Sussman, R.W., Green, G.M. \& Sussman, I.K. (1994) Satellite imagery, human ecology, anthropology and deforestation in Madagascar. Human Ecology, 22, 333-354.

Wells, M. \& Brandon, K. (1992) People and Parks: Linking Protected Area Management with Local Communities. The World Bank, Washington, USA.

White, F. (1983) The Vegetation of Africa: a Descriptive Memoir to Accompany the UNESCO/AETFAT/UNSO Vegetation Map of Africa. Natural Resources Research 20, UNESCO, Paris.

Wilson, D.E. \& Reeder, D.M. (1993) Mammal Species of the World. A Taxonomic and Geographic Reference. Smithsonian Institute Press, Washington and London.

WCMC (1991) Guide de la Diversité de Madagascar. World Conservation Monitoring Centre, Cambridge, UK.

WFF (1993) Coral reefs and coastal zone of Toliara: conservation and development through ecotourism. Unpublished pre-project report. World Wide Fund for Nature-Madagascar, Antananarivo, Madagascar.

WWF (1997) Toliara Sustainable Energy Project WWF Summary Progress reports, Vol. 5. World Wide Fund for Nature, Gland, Switzerland.

WWF \& IUCN (1994) Centres of Plant Diversity. A Guide and Strategy for their Conservation. 3 Volumes, World Wide Fund for Nature and IUCN, IUCN, Cambridge, UK. 
Wright, P. (1997) The future of biodiversity in Madagascar: a view from Ranomafana National Park. In Natural Change and Human Impact in Madagascar (eds S.M. Goodman and B.D. Patterson). Smithsonian Institute Press, Washington, DC.

Yount, J.W., Tsiazonera \& Tucker, B.T. (in press) Constructing Mikea identity: past or present links to forest and foraging. In Ethnohistory, Special Isste on Madagascar (ed. J.C. Kaufmann).

ZICOMA (1999) Projet ZICOMA, Antananarivo, Madagascar. [in French].

\section{Biographical sketches}

Nathalie Seddon is currently based in the Department of Zoology, Cambridge University, UK, where she is writing up her PhD thesis on the ecology of subdesert mesites. Her research interests encompass behavioural ecology and conservation biology, and she has been involved in research and biodiversity assessment projects in Peru, Tanzania and India.

Joe Tobias has a behavioural ecology $\mathrm{PhD}$ from Cambridge University and is currently a freelance ornithologist and writer. He is involved with BirdLife International's Asian Red Data Book Project and has undertaken survey's of threatened birds and mammals in a variety of South American, Asian and East African countries.

James Yount is currently writing his PhD thesis at the University of Wisconsin on the Mikea people and land use in the Mikea Forest. He is developing a botanical and mammal inventory for the region and is mapping its vegetation and human use. He plans to work as an independent consultant on the cultural and ecological dimensions of conservation, development, health and population stabilization.

Julien Rémi Ramanampamonjy is curator of birds at the Parc Botanique et Zoologique de Tsimbazaza in Antananarivo, Madagasacar. He has contributed to research and conservation projects throughout Madagascar, his particular interest lying in environmental education and in working closely with local communities. During the course of three field-seasons, he developed local conservation initiatives in the southern Mikea Forest.

Stuart Butchart is a research fellow at the Department of Zoology, University of Cambridge, UK, currently studying brood parasitism in cuckoos. His conservation interests have involved surveys and status assessments for threatened birds and mammals in Indonesia, Paraguay and Peru.

Hiarinirina Randrianizahana works for the Ministère des Eaux et Forets in Antananarivo, Madagasacar. He was instrumental in setting up this project and conducted community-based work in the southern Mikea Forest. He has an active interest in conservation projects throughout Madagascar. 